\title{
Technology Enhanced Formative Assessment for Students' Motivation in Mathematics at Elementary Level
}

\author{
* Abida Shaheen, PhD Scholar (Corresponding Author) \\ ** Dr Farhana Khurshid, Assistant Professor \\ *** Dr Muhammad Saeed Khan, Assistant Professor
}

\begin{abstract}
Technology Enhanced Formative Assessment (TEFA) is an advanced and evidence-based pedagogical approach for science and mathematics teaching using a classroom response system. Question-driven instruction, dialogical discourse, formative assessment, and meta-level communication are four core principles on which TEFA is built upon. These are implemented through a question cycle in the classroom. Eight weeks duration intervention study was carried out in two urban high schools, one from each stratum (i.e., boys and girls) using a non-equivalent comparison group quasi-experimental design on a sample of 183 participants. The study participants included 42 girls and 47 boys in the experimental group, whereas 54 girls and 40 boys in the control group from the 8th-grade mathematics class. Students' mathematics motivation survey using IMI (i.e., intrinsic motivation inventory) was used to measure students' mathematics learning motivation levels. Twoway ANOVA was conducted to assess the motivation level of the students. Analysis of the results showed that the experimental group motivation level was significantly higher than the control group.

Keywords: Classroom Response System, Pedagogy, Mathematics, Motivation, Formative Assessment

\section{Introduction}

Teachers practice various instructional methods to involve and activate their students in the teachinglearning process. Activating students is a difficult task as many intrinsic and extrinsic elements are motivating forces for students. Class Response System is of an excellent technique to sustain an extreme level of student involvement and motivation as the lecture method ends motivation and reduces concentration on content (Duncan, 2005). According to Beatty (2004) and McLoughlin (2008), CRS-based instruction creates students' active participation in the learning process. The implementation of technology in the classroom has been discussed by Muller, Sharma, and Eklund, (2006) and has been widely used at the postsecondary level as compared to the use of CRS at the secondary level (Lively, 2010; Sartori, 2008). Further, these studies focused on the use of CRS only in the classroom and not talked about the pedagogy involved. The application of CRS based instructions in elementary and secondary education is still uncommon. To bridge this gap, the present study has been designed to explore the effectiveness of TEFA for student's mathematics learning motivation at the elementary level.
\end{abstract}

\section{Literature Review}

Research on the use of a CRS shows that this technology increases the motivation of college students (Gauci et al., 2009). However, to get the maximum benefit from this technology, a suitable pedagogy should be used with CRS. Numerous pedagogies relate to the Active Learning theories, Constructivism, and implementation of CRS technology. Some out of these are Peer Instruction (Crouch \& Mazur, 2001), Assessing to Learn (Dufrense \& Gerace, 2004), and Technology-Enhanced Formative Assessment (TEFA) (Beatty \& Gerace, 2009). Technology-Enhanced Formative Assessment (TEFA) is one such pedagogy for science and mathematics teaching with classroom response technology (Beatty., et al, 2009). Dufresne et al. (1996) developed a pedagogy "Assessing

\footnotetext{
* Department of Education, Fatima Jinnah Women University, Rawalpindi Email: hr.7118@gmail.com

** Department of Education, Fatima Jinnah Women University, Rawalpindi

Email: Farhana_edu@ hotmail.com

*** Department of Education, University of Haripur, Haripur Email: $\underline{\text { saeedagha03@ gmail.com }}$
} 
to learn" that used CRSs for formative assessment. Technology-Enhanced Formative Assessment (TEFA) is a modified form of a pedagogy "Assessing to learn" developed by Beatty and Gerace(2009). TEFA is built on four fundamental principles categorized as: question-driven instruction, dialogical discourse, formative assessment, and meta-level communication. These four principles are best implemented through the below question cycle.

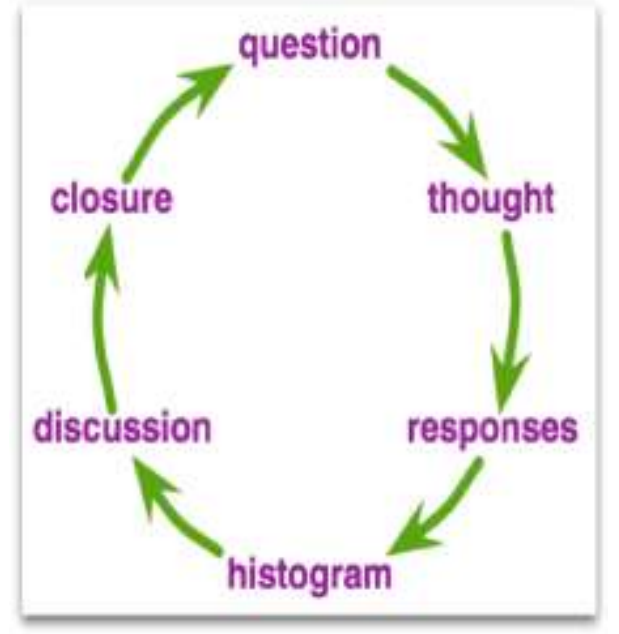

Figure 1. Question Cycle

Through this question cycle, the teacher asks a conceptual question to students within their zone of proximal development (Vygotsky 1978). Students think about the question alone or in small groups then record the responses through CRS. CRS displays a histogram of responses on the teacher's computer. After that whole-class discussion starts. Teachers elicit from students as many reasons and explanations as possible. This discussion is followed by a small lecture by the teacher and in this way, this question cycle ends and starts with another challenging question (Beatty \& Gerace, 2009).

Class Response System (CRS) is mostly used at the postsecondary level (Beatty, 2004; Beatty \& Gerace, 2009) and is not more popular at the secondary level. Students become active learners during instruction by using CRS (Jones, 2009). Research shows that students are more engaged and motivated in CRS classrooms (MacGeorge et al. 2008). Use of CRS technology motivated students to answer questions correctly, (a) improve student learning, (b) increased test scores, (c) improved student attention, and (d) enhanced interest of students in course content (Prather \& Brissenden, 2009). CRS enhanced student engagement and motivation in crowded classes at the postsecondary level (Hall, et al. ,2005). Cain et al. (2009) indicated that the use of CRS increased student attention and motivation (Cain et al., 2009). CRS based instructions, peer instruction, enhanced student achievement and motivation at the secondary level (Allison, 2012). CRS improved student learning and motivation at the secondary level (Satori, 2008). CRS enhanced student motivation in 10th to 12th-grade students (Kay \& Knaack, 2009). CRS improved student performance and motivation of science students in grade $6^{\text {th }}$ (Bloemers, 2004).

\section{Objective}

The main objective of the study is as under:

In what ways the Technology-Enhanced Formative Assessment affect students' subject-related motivation as compared to traditional instructional methods?

\section{Method \\ Research Design}

A static group experimental design was applied to perform the present study. Permission was obtained from the principals of the schools where this research was to be conducted. Permission for participation in the study was requested and obtained from teachers and parents of all the student participants at the beginning of the experiment. All teachers and participants were made aware that they had the choice to leave the research at any time. Students were encouraged by their teachers that participation and responses collected during this research were not related to them as individuals, but all gathered data would only be used for research purposes 


\section{Sample}

The context of the present study is TEFA which is a CRS-based pedagogy focused on the philosophy of the constructivist paradigm that encourages students to take an active role in the teaching-learning process. The study was organized in two high schools (i.e., boys and girls) of urban area Haripur District Khyber Pakhtunkhwa Province, Pakistan. Two classes of grade $8^{\text {th }}$ were selected from each school as an experimental and control group. Groups were assigned to each class. The sample size in each school is shown in the following table.

Table 1. Sample size

\begin{tabular}{llll}
\hline Stratum & Control Group & Experimental Group & Total \\
\hline Boys School & 40 & 47 & 87 \\
Girls School & 54 & 42 & 96 \\
Total & 94 & 89 & 183
\end{tabular}

\section{Data Collection Instrument}

Students' mathematics motivation survey using IMI (i.e., intrinsic motivation inventory) was used to measure students' mathematics learning motivation levels. Survey items established on two Dutch studies, the Intrinsic Motivation Inventory (Meijer, Eck, \& Felix, 2008) and the COOL 5-18 cohort study (Driessen, et, al. 2012), were managed to measure students subject related motivation. Items were measured on a five-point Likert scale ranges from $(1=$ completely disagree, $2=$ mostly disagree $3=$ agree to some extent, $4=$ mostly agree $5=$ completely agree). Though the reliability of the instrument is well established in different contexts but Pakistani context, its reliability was calculated using Cronbach's alpha which was .91. Both the control and experimental group students answered to students' mathematics motivation survey at the end of the intervention.

\section{Procedure}

\section{Training of teachers and students on classroom response system}

Experimental group mathematics teachers were given one-month training on TEFA. Experimental group participants in both schools (i.e., boys and girls) were also given training on the operation of the classroom response system (i.e., clickers) for one week before the intervention.

\section{Intervention}

During eight week intervention, the control group at both selected schools (i.e., boys and girls) were taught on average five hours a week using traditional instructional method, where the teacher used chalk and board, students noted down questions on their notebooks and were bound to reproduce the same on their homework copy on the next day. The experimental group was taught in a separate classroom specifically managed for Technology-Enhanced Formative Assessment (TEFA) pedagogy (i.e., CRS-based instruction).

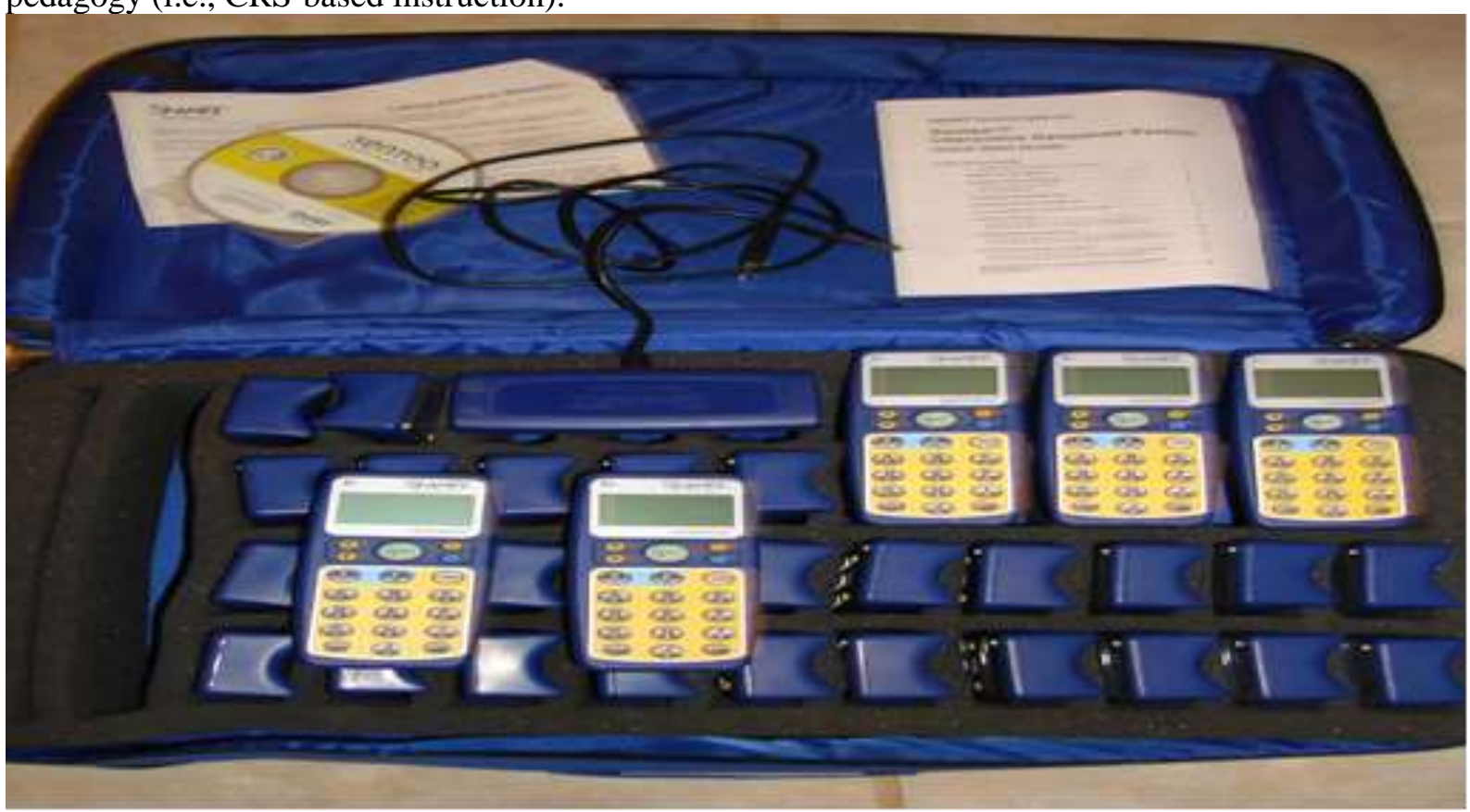

Figure 2: Interactive Classroom Response System (clickers) 
In the TEFA classroom, a classroom response system(clickers) was used to collect students' responses to multiple-choice questions before and during instructions. Each student was assigned a unique ID number; therefore, students were identified on the system through their ID numbers along with their names. A multimedia was used to display questions and students' responses on the screen when necessary during the instructional sequence. Clicker (i.e., a handheld student response device used by students to submit their responses to MCQs through radio frequency) was given to students. Teacher computer was connected to these clickers through radio frequency receiver wireless technology. The teacher was able to display the relevant question to students on screen as and when required in real-time. The teacher posed conceptual challenging question through the classroom response system. Time was given to students to think over it alone and in small groups, then respond through CRS (i.e., clickers). When the students completely decided about their response choice to a multiple-choice question, they were used to click on their selected response choice and submit answer through CRS. The teacher received students' responses on their computer through software and responses histogram and pie-chart were automatically displayed (see fig 2 and 3). Thus, the teacher was able to check students' responses in real-time, judged their conceptual comprehension, and adjusted instructions accordingly in real-time.

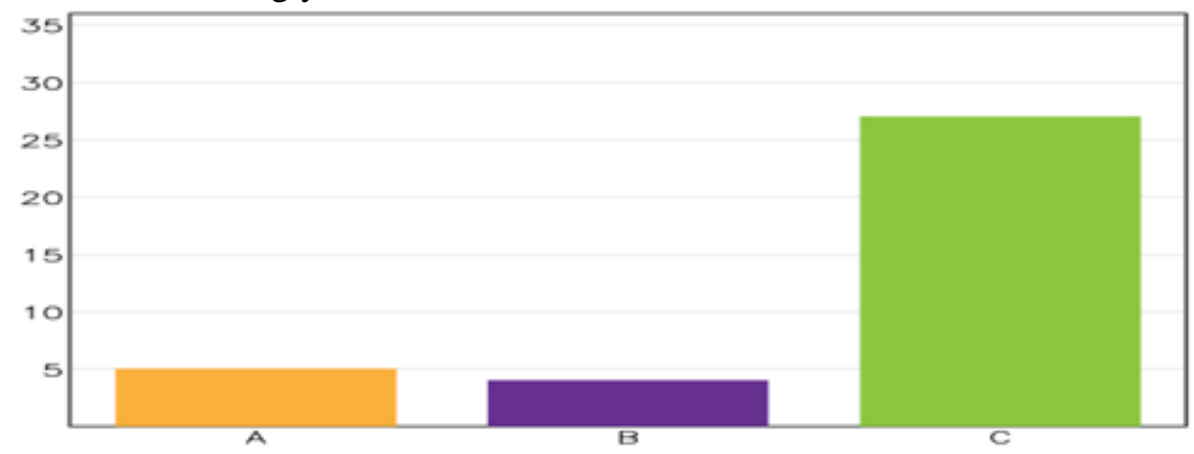

Figure 3. A histogram of students' responses to a question posed by the teacher

\section{Results}

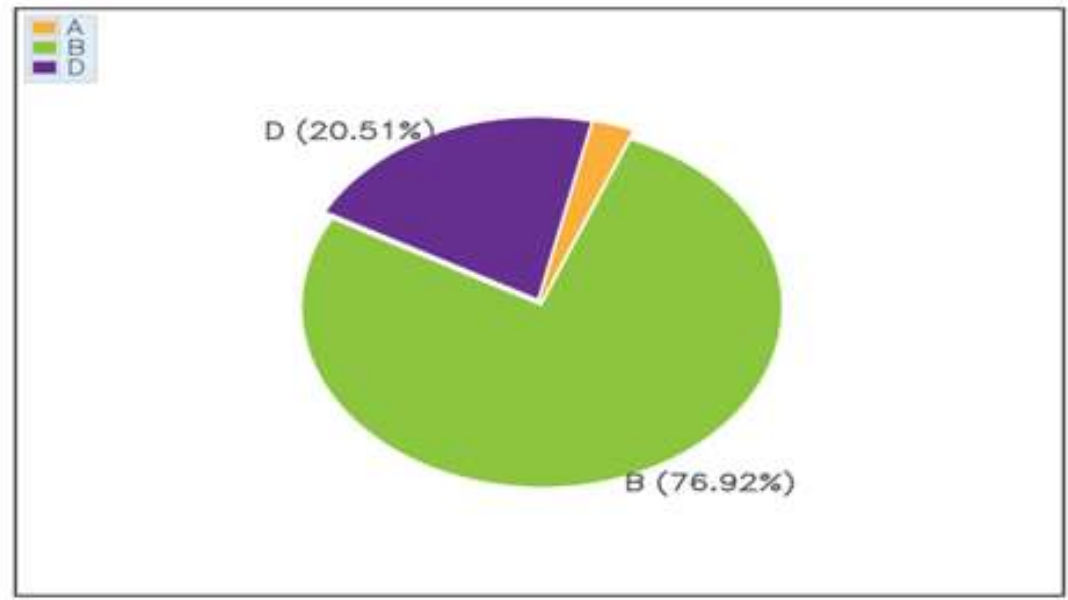

Figure 4. A Pie Chart of students' responses to a question posed by the teacher

The main objective of this study was to find out the impact of Technology-Enhanced Formative Assessment pedagogy on students' mathematics motivation at elementary level in two high schools in Haripur District. After the intervention, the intrinsic motivation inventory (IMI) survey was used to measures a student's mathematics motivation level.

Kaiser Meyer Olkin (KMO) and Bartlett's test measures the strength of correlations among items. KMO statistics of $.88, p=.000$ is high and statistically significant that provide evidence that sample size is adequate to carry out a further factor analysis and the Bartlett's test of Sphericity is also statistically significant, it further corroborate that there are strong correlations among scale items. 
Table 2. KMO and Bartlett's Test

\begin{tabular}{lll}
\hline KMO and Bartlett's Test & & \\
\hline Kaiser-Meyer-Olkin Measure of & & .880 \\
Sampling Adequacy. & Approx. Chi-Square & 572.886 \\
Bartlett's Test of Sphericity & Df & 10 \\
& $p$-value & .000 \\
\hline
\end{tabular}

All the items were strongly correlated with values between .57 to .72 . It showed that all items were measuring the same construct.

Table 3. Inter-Item Correlation Matrix

\begin{tabular}{cllllll}
\hline Inter-Item Correlation Matrix & & & & & \\
\hline S. No. & Items Description & $\mathbf{1}$ & $\mathbf{2}$ & $\mathbf{3}$ & $\mathbf{4}$ & $\mathbf{5}$ \\
\hline $\mathbf{1}$ & Mathematics lessons are boring & & & & & \\
$\mathbf{2}$ & I like mathematics & .690 & & & \\
$\mathbf{3}$ & I enjoy doing mathematics assignments & .697 & .658 & & \\
$\mathbf{4}$ & I think mathematics is interesting & .633 & .568 & .723 & \\
$\mathbf{5}$ & I think mathematics is important & .660 & .634 & .690 & .699 & \\
\hline
\end{tabular}

Table 4. IMI Survey items loading

\begin{tabular}{lc} 
Items Description & Component \\
& $\mathbf{1}$ \\
\hline Mathematics lessons are boring (Negatively worded question thus reverse for analysis) & .860 \\
I like mathematics & .827 \\
I enjoy doing mathematics assignments & .883 \\
I think mathematics is interesting & .847 \\
I think mathematics is important & .861 \\
\hline
\end{tabular}

Extraction Method: Principal Component Analysis. a. 1 component extracted.

Further, only one factor was extracted explained $73.25 \%$ variance when used the principal components technique with varimax rotation and all the items were loaded on a single factor with strong loadings. It further supports the stance that there was a strong coherence among items to measure the construct of students' mathematics motivation.

Further, the participants' reply rate to the survey was $100 \%$ (89/89) for treatment group and $100 \%$ (94/94) for the control group. An ANOVA was applied to analyze the scores for each group for the IMI. For this purpose, assumptions of ANOVbetween-groups. Those were independence of observations, technology-enhanced homogeneity of variance and normality. A two-way between groups ANOVA was performed to compare the impact of technology enhanced formative assessment (TEFA) pedagogy on students' mathematics motivation. Further, participants were distributed into two groups based upon the instructional method (Control Group taught with traditional instruction method; Experimental Group taught with technology-enhanced formative assessment pedagogy). Further, Participants were divided into two groups based upon the parental support in homework (parental support $=$ yes/no). Out of a total of 183 study participants, 69 were received parental support during intervention which becomes $38 \%$ of the total sample.

The outcome variable was found to be normally distributed and equal variances are assumed based upon results of Leven's test $(\mathrm{F}(1,181)=.1 .953, p=.123)$. There was a statistically significant difference in students mathematics motivation mean scores $(\mathrm{F}(1,182)=13.012, p=.000)$ based on the instructional method. The magnitude of difference in the means (means difference $=.345$ ) and effect size was medium (partial eta squared $=.068$ ) with strong observed power .948 . Results indicate that the instructional method explains a $6.8 \%$ variance in students' mathematics motivation. It means the treatment was effective to improve students' mathematics motivation. This finding is aligned with previous research findings where statistically significant improvements were observed in students' motivation for technology-enhanced instructional method interventions. Further, students' parental support in their homework assignments and home study in mathematics was found to be the significant predictor of students mathematics learning motivation $(\mathrm{F}(1,182)=6.828, p=.010)$. The effect size of students' parental support was small (partial eta squared=.037) with observed power .74 . Results indicate that students parental support explains a 3.7\% variance in students' mathematics 
learning motivation. From the below figure it is evident that students' parental support significantly improved students' mathematics learning motivation across control and experimental groups, but the rise in students' mathematics motivation for the TEFA group is higher than for the control (i.e., traditional instructional method) group.

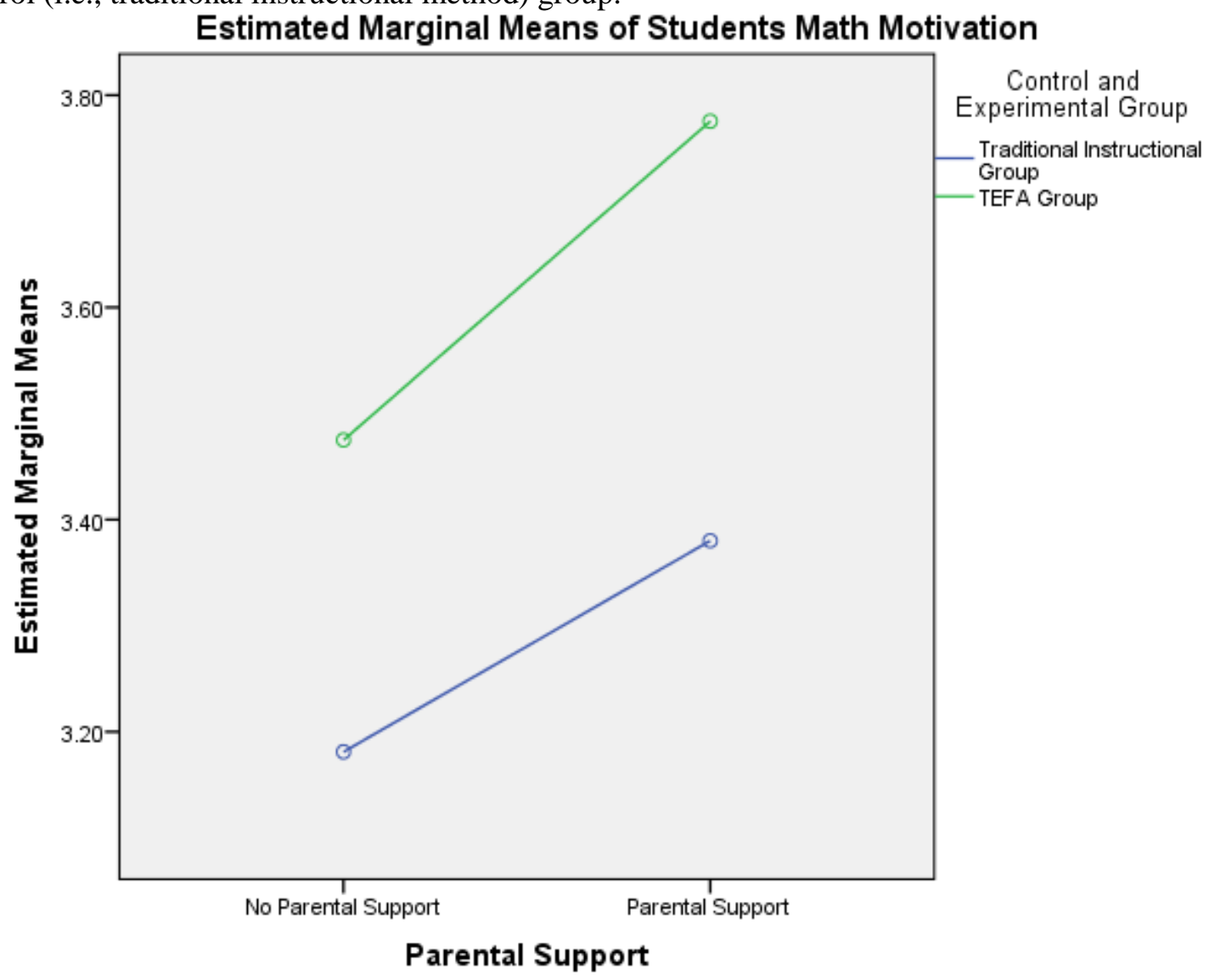

Figure 5. Parental Support and Mathematics Learning Motivation Across Groups

It shows that if TEFA is implemented in regular classrooms in combination with substantial students' parental support then higher learning motivation can be achieved. These results are in line with previous researches that used technology-based formative assessment, peer instruction, and other technology-based pedagogies. One of the reasons for the improvement in students learning motivation through parental support in homework may be the easiness that students felt when parents put their efforts to resolve their misconceptions about mathematics topics. They start to see mathematics as an easy to learn the subject and thus become more motivated to learn mathematics more enthusiastically.

Table 5. Two-way ANOVA Results on Students' Mathematics Motivation Scale Scores

\begin{tabular}{llllll}
\hline Source & df & F & Sig. & Partial Eta Squared & Observed Power \\
\hline Corrected Model & 1 & 22.974 & .000 & .068 & .99 \\
Parental Support & 1 & 6.828 & .010 & .037 & .95 \\
Pedagogy & 1 & 12.012 & .000 & .068 & .74 \\
\hline
\end{tabular}

a. $\quad$ R Squared $=.150$ (Adjusted R Squared $=.135$ )

b. $\quad$ Computed using alpha $=.05$

\section{Discussion}

The present study explored that in what ways technology-enhanced Formative Assessment is effective in improving students' mathematics-related motivation as compared to traditional instructional methods in mathematics at the elementary level.

The present study answers the aforesaid question that students who got TEFA instruction had higher mean scores for mathematics learning motivation than the students who received instruction through the traditional method.

This finding of ANOVA revealed that the use of TEFA instruction enhanced student mathematics learning motivation. Further, during data analysis, it was revealed that parental support during student's homework for mathematics at the middle level was a statistically significant impact 
on students' mathematics learning motivation in both treatment and control group participants. The parental support effect indicated that the students in both groups with parental support in their mathematics homework were more motivated than students who were in the same group but did not receive parental support during their homework of mathematics in eight grades. Although there was no interaction effect between treatment condition and parental support but the rate of increase in students' mathematics learning motivation for those who received parental support was higher in TEFA group students than their counterparts in the control group. This is evident from the two-way graph as well. Thus, parental support positively enhanced student's motivation to learn mathematics in eighth grade.

Results of this study support previous research findings, which proves that TEFA enhance student mathematics learning motivation level positively. Students are more engaged and more answerable for their learning by CRS based pedagogy (Zhu, 2007). Students perceive that motivation is increased using CRS-based pedagogies (Judson \& Sawada, 2006). Attention is enhanced with the use of CRS technology and CRS based pedagogies (Horowitz, 1988). Students believe CRS and its implementation in regular classrooms with pedagogy is interesting and enjoyable and increase student motivation (Albon \& Jewels, 2007). In TEFA, students' misconceptions are timely captured through multiple choice questions particularly designed with effective distractors. Through capturing student's responses to these questions, teachers decide about students misunderstanding of the concept and address those misconceptions through timely feedback. Previous researches have shown that timely feedback also significantly improves students' conceptual comprehension. This in turn enhances students subject learning motivation level. The same situation arises when TEFA is effectively implemented in the mathematics classroom at the elementary level. Hence results of this study corroborate the findings of past research that used technology-based pedagogies. The results of this study further show that parental support also contributes to subject related motivation.

\section{Limitations and Recommendations}

The present study examined the impact of TEFA on students' subject-related motivation in mathematics at the elementary level. However, this study faced a few limitations. First, the present research was conducted in two urban high schools in one district in one subject area with a sample of 183 participants. Future studies are encouraged to apply and expand this research work including both rural and urban areas of different districts in different subject areas to improve study generalizability. Replication of this study could be done with any of the following variations: using (a) a different validated survey for measuring motivation, (b) expanding the length of time for the instructional unit beyond eight-week time (c) using a different unit of study in math; (d) using a different subject area, (e) using a different grade level in the elementary setting, (f) Instead of quasi-experimental design, strong experimental design(random assignment of study participants) could be applied to improve the validity of the study.

Second, quantitative data was gathered in a self-reported way for analysis, so different qualitative research designs can be implemented to explore more information about the research problem at hand. Qualitative data such as semi-structured interviews, focus group discussions with students, or classroom observation, could be combined to develop a better understanding of the research question and corroborate the results from quantitative data.

\section{References}

Adams, H., \& Howard, L. (2009). Clever clickers: Using audience response systems in the classroom. Library Media Connection, 28(2), 54-56.

Albon, R. J., \& Jewels, T. (2007). The impact of audience response systems in a multicultural Asian context. In R. J. Atkinson, C. McBeath, S. K. A. Soong, \& C. Cheers, (Eds.), ICT: Providing choices for learners and learning. Proceedings ascilite Singapore 2007 (pp. 10-19). Singapore: Centre for Educational Development, Nanyang Technological University. Retrieved from http://www.ascilite.org.au/conferences/singapore07/procs/albon.pdf

Barnett, J. (2006). Implementation of personal response units in very large lecture classes: Student perceptions. Australasian Journal of Educational Technology, 22(4), 474-494.

Barrett, M. S., Bornsen, S. E., Erickson, S. L., Markey, V., \& Spiering, K. (2005). The personal response system as a teaching aid. Communication Teacher, 19(3), 89-92. doi:10.1080/ 14704620500201806 
Beatty, I. (2004). Transforming student learning with classroom communication systems. Educause Centre for Applied Research Bulletin, 3, 2-13. Retrieved from http://net.educause.edu/ ir/library/pdf/ERB0403.pdf

Beatty, I. D., \& Gerace, W. J. (2009). Technology-enhanced formative assessment: A research-based pedagogy for teaching science with classroom response technology. Journal of Science Education and Technology, 18(2), 1146-1162. doi:10.1007/s10956-008-9140-4

Beatty, I. D., Leonard, W. J., Gerace, W. J., \& Dufrense, R. J. (2006). Question driven instruction: Teaching science (well) with an audience response system. In D.

Banks (Ed.), Audience Response Systems in Higher Education: Applications and Cases (pp. 96-115). Hershey, PA: Information Science Publishing.

Berry, J. (2009). Technology support in nursing education: Clickers in the classroom. Nursing Education Research, 30(5), 295-298. doi:10.1043/1536-5026-30.5.295

Bloemers, B. (2004). Classroom performance systems in the classroom. Retrieved from Michigan State University website: https://www.msu.edu/ bloemer3/documents/812CPS.doc

Black, P., \& Wiliam, D (1998). Inside the black box: Raising standards through classroom assessment. London: School of Education, King's College

Caldwell, J. E. (2007). Clickers in the large classroom: Current research and best-practice tips. CBE Life Science Education, 6(1), 9-20. doi:10.1187/cbe.06-12-0205 Calhoun, J. (n.d.). Classroom response systems. Retrieved from Carleton College, Science

Creswell, J. W. (2005). Educational research: Planning, conducting, and evaluating quantitative and qualitative research. Upper Saddle River, NJ: Pearson.

Crouch, C. H., \& Mazur, E. (2001). Peer instruction: Ten years of experience and results. American Journal of Physiology, 69(9), 970-977. doi:10.1119/1.1374249

Crouch, C. H., Watkins, J., Fagen, A. P., \& Mazur, E. (2007). Peer instruction: Engaging students one-on-one, all at once. In E. F. Redish and P. J. Cooney (Series Eds.), Reviews in Physics Education Research: Vol. 1. Research-based reform of university physics (pp. 1-55). Retrieved from http://www.compadre.org/Repository/document/ServeFile.cfm?ID=4990\&Do $\mathrm{cID}=21$

Conoley, J., Moore, G., Croom, B., \& Flowers, J. (2006). A toy or a teaching tool? The use of audience response systems in the classroom. Techniques (The Journal of the Association for Career and Technical Education), 81(7), 46-49. Retrieved from http://www.cals.ncsu.edu/ agexedEGETYYHH/people/moore/intro.html

Dufresne, R. J., \& Gerace, W. J. (2004). Assessing-to-learn: Formative assessment in physics instruction. The Physics Teacher, 42(8), 18-23. doi:10.1119/1.1804662

Dangel, H. L., \& Wang, C. (2008). Student response systems in higher education: Moving beyond linear teaching and surface learning. Journal of Educational Technology Development and Exchange, 1(1), 93-99. Retrieved from http://www.sicet.org/journals/jetde/jetde08/ paper08.pdf

Driessen, G., Mulder, L., \& Roeleveld, J. (2012). Cohortonderzoek COOL 5-18: Technisch rapport basisonderwijs, tweede meting 2010/11 [Technical report primary education, measurement 2010/2011]. Retrieved from the COOL website: http://www.cool5-18.nl/publicatiesbo/

Fies, C., \& Marshall, J. (2006). Classroom response systems: A review of the literature. Journal of Science Education and Technology, 15(1), 101-109. doi:10.1007/s10956-006-0360-1

Fagen, A., Crouch, C., \& Mazur, E. (2002). Peer instruction: Results from a range of classrooms. The Physics Teacher, 40(4), 206-209. doi:10.1119/1.1474140

Greer, L., \& Heaney, P. J. (2004). Real-time analysis of student comprehension: An assessment of electronic student response technology in an introductory earth science course. Journal of Geoscience Education, 52(4), 345-351. doi:10.1177/1469787407081885

Harlow, J., Kushnir, L. P., Bank, C., Browning, S., Clark, J., Cordon, A., . . Serbanescu, P. (2008). What's all the clicking about? A study of classroom response systems used at the University of Toronto. Retrieved from http://www.upscale.utoronto.ca/PVB/Harrison/Clickers/Clickers_ PVB.pdf

Holmes, R. G., Blalock, J. S., Parker, M. H., \& Haywood, V. B. (2006). Student accuracy and evaluation of a computer-based audience response system. Journal of Dental Education, 70(12), 1355-1361. Retrieved from http://www.jdentaled.org/content/70/12/1355.full.pdf 
Hake, R. R. (1998). Interactive-engagement vs. traditional methods: A six-thousand-student survey of mechanics test data for introductory physics courses. American Journal of Physics, 66(1), 6474. doi:10.1119/1.18809

Higgins, K., Huscroft-D'Angelo, J., and Crawford L. (2017). Effects of Technology in Mathematics on Achievement, Motivation, and Attitude: A Meta-Analysis. Journal of Educational Computing Research. DOI: 10.1177/0735633117748416

Hunsu, N.J., Adesope, O., \& Bayly, D.J. (2016) A meta-analysis of the effects of audience response systems (clicker-based technologies) on cognition and affect. computers and education 94(2016) 102-119

Jackson, J. (2007). Audience or personal response systems (aka, -clickers $\|$ ) - Tools or toys? Science Education at the Crossroads. Retrieved from http://www.sciedxroads.org/2007/ JonJackson.pdf

Kay, R., \& Knaack, L. (2009). Exploring the use of audience response systems in secondary school science classrooms. Journal of Science Education \& Technology, 18(5), 382-392. doi:10.1007/s10956-009-9153-7

Kay, R. H., \& LaSage, A. (2009). Examining the benefits and challenges of using audience response systems: A review of the literature. Computers \& Education, 53(3), 819-827. doi:10.1016/j.compedu.2009.05.001

Lasry, N., \& Findlay, J. (2007). Clickers in the Classroom: Implementing peer instruction in Cegep. Paper presented at the 30th Annual McGraw-Hill Ryerson National Teaching, Learning, and Technology Conference: The Spirit of Inquiry -Developing Critical Thinking, Creativity and Community, Montreal, Quebec. Retrieved from http://www.cdc.qc.ca/parea/786494_lasry_ john_abbott_PAREA_2006.pdf

Lasry, N., Mazur, E., \& Watkins, J. (2008). Peer instruction: From Harvard to the two-year college. American Journal of Physics, 76(11), 1066-1069. doi:10.1119/1.2978182

Lively, B. R. (2010). A study of the impact of the classroom performance system (CPS) on fourth and fifth-grade student social studies academic performance (Doctoral dissertation). Retrieved from ProQuest Dissertations and Theses database. (ATT 3409895)

MacArthur, J. R., \& Jones, L. L. (2008). A review of literature reports of clickers applicable to college chemistry classrooms. Chemistry Education Research and Practice, 9(3), 187-195. doi:10.1039/b812407h

Mazur, E. (1997). Peer Instruction: A user's manual. New Jersey: Prentice-Hall. doi:10.1063/1.881735

Mazur, E. (2011). Mazur Group: Chaos in the classroom? Retrieved from http://mazur.harvard.edu/ research/detailspage.php?rowid=8

McDonald, J. H. (2009). Handbook of Biological Statistics (2nd ed.). Baltimore, Maryland: Sparky House Publishing.

Mayer, R. E., Stull, A., DeLeeuw, K., Almeroth, K., Bimber, B., Chun, D., . . Z Zhang, H. (2009). Clickers in college classrooms: Fostering learning with questioning methods in large lecture classes. Contemporary Educational Psychology,34(1), 51-57. doi:10.1016/j.cedpsych.2008. 04.002

Mazur, E. (1997). Peer Instruction: A user's manual. New Jersey: Prentice-Hall. doi:10.1063/1.881735

Mazur, E. (2011). Mazur Group: Chaos in the classroom? Retrieved from http://mazur.harvard.edu/ research/detailspage.php?rowid $=8$

Manzo, K. K. (2009). Student-response systems provide instant classroom feedback: Clickers send student responses with the push of a button. Digital Directions: Trends and Advice for K-12 Technology Leaders, 4. Retrieved from http://www.edweek.org/dd/articles/2009/06/17/ 04feedback.h02.html

Miller, R. L., Santana-Vega, E., \& Terrell, M. S. (2006). Can good questions and peer discussion improve calculus instruction? PRIMUS, 16(3), 193-203. doi:10.1080/10511970608984146

Meijer, J., Eck, E. Van, \& Felix, C. (2008). Leren met meer effect; rapportage van het onderzoek [More effective learning; study report]. Retrieved from SCO-Kohnstamm Instituut website: http://www.informaticavo.nl/docs/ 2009/EindrapportageLMME.pdf

Musselman, M. R. (2008). A critical analysis of teaching with student response systems in middle school classrooms (Doctoral dissertation). Retrieved from ProQuest Dissertations and Theses database. (ATT 3342314) 
Nightingale, J. P., Palumbo, A. K., \& Donahue, J. F. (2008). The impact of personal response systems on student learning in undergraduate business courses. 2008 ASCUE Proceedings, North Myrtle Beach, SC, 57-62. Retrieved from http://www.ascue.org/files/proceedings/2008/ p57.pdf

Poirier, C. R., \& Feldman, R. S. (2007). Promoting active learning using individual response technology in large introductory psychology classes. Teaching of Psychology, 34(3), 194196. doi:10.1080/00986280701498665

Preszler, R. W., Dawe, A., Shuster, C. B., \& Shuster, M. (2006). Assessment of the effects of student response systems on student learning and attitudes over a broad range of biology courses. CBE-Life Sciences Education, 6(1), 29-41. doi:10.1187/cbe.06-09-0190

Rao, S. P., Collins, H. L., \& DiCarlo, S. E. (2002). Collaborative testing enhances student learning. Advances in Physiology Education, 26, 37-41.

Rao, S. P., \& DiCarlo, S. E. (2000). Peer instruction improves performance on quizzes. Advances in Physiology Education, 24, 51-55.

Rigdon, J. (2010). The effect of student response systems in middle school math classrooms (Doctoral dissertation). Retrieved from ProQuest Dissertations and Theses database. (ATT 3403489)

Salkind, N. J. (2007). Statistics for people who (think they) hate statistics: The Excel edition.Thousand Oaks, CA: Sage Publications, Inc.

Sartori, T. M. (2008). An empirical investigation of electronic student response systems in a $\mathrm{K}-12$ school district: The relationship of ongoing assessment on student achievement (Doctoral dissertation). Retrieved from ProQuest Dissertations and Theses database. (UMI 3310871).

Smith, M. K., Wood, W. B., Adams, W. K., Wieman, C., Knight, J. K., Guild, N., \& Su, T. T. (2009). Why peer discussion improves student performance on in-class concept questions. Science, 323(5910), 122-124. doi: 10.1126/science.1165919

Smith, M. K., Wood, W. B., Krauter, K., \& Knight, J. K. (2011). Combining peer discussion with instructor explanation increases student learning from in-class concept questions. Cellbioed (10)1, 55-63. doi:10.1187/cbe.10-08-0101

Slavin, A., \& Shiell, R. (2008). Using clickers to enhance student participation. Teaching at Trent, 11(1), 1-4. Retrieved from http://www.trentu.ca/idc/documents/Fall2008Issue1.pdf

Simpson, V., \& Oliver, M. (2007). Electronic voting systems for lectures then and now: A comparison of research and practice. Australasian Journal of Educational Technology, 23(2), 187-208.

Stowell, J. R., \& Nelson, J. M. (2007). Benefits of electronic audience response systems on student participation, learning, and emotion. Teaching of Psychology, 34(4), 253-258. doi:10.1080/00986280701700391

Shirley, M. L. (2009). A model of formative assessment practice in secondary science classrooms using an audience response system (Doctoral dissertation). Retrieved from ProQuest Dissertations and Theses database. (UMI 3375899)

Smith, M. K., Wood, W. B., Adams, W. K., Wieman, C., Knight, J. K., Guild, N., \& Su, T. T. (2009). Why peer discussion improves student performance on in-class concept questions. Science, 323(5910), 122-124. doi: 10.1126/science.1165919 